\title{
Impact of metals on corrosive behavior of biodiesel-diesel-ethanol (BDE) alternative fuel
}

\author{
Saravana Kannan Thangavelu ${ }^{\text {a, b }}$, Abu Saleh Ahmed ${ }^{c}$, Farid Nasir Ani ${ }^{\text {a, * }}$ \\ a Department of Thermo Fluids, Faculty of Mechanical Engineering, Universiti Teknologi Malaysia, UTM, 81310 Skudai, Johor D.T., Malaysia \\ ${ }^{\mathrm{b}}$ Faculty of Engineering, Computing and Science, Swinburne University of Technology, 93350 Kuching, Sarawak, Malaysia \\ ${ }^{c}$ Department of Mechanical and Manufacturing Engineering, Faculty of Engineering, Universiti Malaysia Sarawak, Sarawak, Malaysia
}

\section{A R T I C L E I N F O}

\section{Article history:}

Received 30 July 2015

Received in revised form

26 January 2016

Accepted 3 March 2016

Available online 19 March 2016

\section{Keywords:}

Biodiesel-diesel-ethanol (BDE)

Corrosion

Mild steel

Copper

Aluminum

\begin{abstract}
A B S T R A C T
Corrosive behavior of biodiesel-diesel-ethanol (BDE) fuel blends upon exposure to metals, namely, mild steel, copper and aluminum was studied by static immersion at room temperature and $60^{\circ} \mathrm{C}$. The change of fuel properties, i.e., total acid number, density, viscosity, calorific value, flash point, and color changes were investigated. Moreover, fuel compositional changes, such as water content, oxidation product level, and metal elements in the fuel blends were examined. Finally, the effect of fuel blends on corrosion rate (CR), morphology of corrosion products, and chemical structure of metals were studied. Results revealed that the CR of metals in BDE fuels is in the order: aluminum < mild steel < copper at both temperature conditions. The degradation of fuel properties and corrosion rate of metals in BDE fuel blends are lower than neat biodiesel (B100), whereas higher than petro-diesel (B0). Corrosiveness of B20D75E5 is lower than B20D70E10 upon exposure to metals.
\end{abstract}

๑) 2016 Elsevier Ltd. All rights reserved.

\section{Introduction}

The increasing demands of petroleum-based fuels, due to the rapid development of industry and automotive society, coupled with the environmental pollution issues (greenhouse gas emissions) have motivated the efforts on discovering new alternative fuels. Biofuels, especially ethanol/bioethanol and biodiesel have gained progressive importance as alternative fuels for internal combustion engines [1]. The blends of diesel and ethanol could be used in existing diesel engines without engine modification, but the major drawback in diesel-ethanol (DE) fuel blends is, that ethanol is immiscible in diesel over a wide temperatures and water content, because of their chemical structure and characteristics. These can results in fuel instability due to phase separation; however, biodiesel is successfully added to DE blends to prevent the phase separation and instability [2]. Biodiesel is highly miscible in both diesel and ethanol; moreover, can act as an emulsifier for DE blend to form biodiesel-diesel-ethanol (BDE) blend, which can be used in diesel engines. The addition of biodiesel in DE blends dramatically improves the solubility of ethanol in diesel over a wide range of temperature, and the $\mathrm{BDE}$ fuel blends are stable well below

\footnotetext{
* Corresponding author.

E-mail address: farid@mail.fkm.utm.my (F.N. Ani).
}

zero temperature [3]. As reported by Shahir et al. [3] in their recent review, a maximum of $30 \%$ biodiesel (ethyl or methyl ester) and ethanol blend can be added to diesel fuel effectively. In addition, most of the researchers recommend that a maximum of $20 \%$ (Vol.) biodiesel and 10\% (Vol.) ethanol can be used in diesel engine for better engine performance and emissions [4-7].

Biodiesel-diesel-ethanol (BDE) blend represent an important alternative fuel for diesel engines; however, changes in the fuel composition and the introduction of new alternative fuel often results in corrosion and degradation of the automobile fuel system parts. The presence of water, organic acids, aldehydes, peroxides, ketones, and esters in oxygenated fuel causes corrosion in fuel system materials; in addition, degrades the properties of fuel [8]. The diesel engine parts made from mild steel, such as fuel tank, fuel lines, and fuel tube outlet; copper, such as, fuel tank gasket, washer, and bushing; and aluminum, such as fuel pump, fuel filters, and fuel feed pump are normally affected by the fuel blends [9].

Many researchers have investigated the corrosion behavior of metallic materials, namely, mild steel, copper, aluminum, stainless steel, brass, magnesium and cast iron in different biodiesel, such as palm oil, rapeseed oil and sunflower oil [10-19]. Literature show a gap that there is no study reported on corrosion behavior of metals, especially, mild steel and aluminum in biodiesel-diesel-ethanol (BDE) fuel blend, and the corrosive nature of BDE fuel on metallic 